\title{
PENYUSUNAN PERANGKAT KONTROL KUALITAS PERANGKAT LUNAK BERBASIS ISO 25030 STUDI KASUS: APLIKASI SCHOOL SOCIAL NETWORK (SSN)
}

\author{
Ahmad Holil Noor Ali, Adrian Nugraha Putra, Anisah Herdiyanti \\ Jurusan Sistem Informasi, Fakultas Teknologi Informasi, Institut Teknologi Sepuluh Nopember \\ Kampus Keputih, Sukolio Surabaya 60111 \\ Telp: (031) 5999944, Fax: (031) 5964965 \\ E-mail: holil@its-sby.edu
}

\begin{abstract}
School Social Network (SSN) is school based software program that offers functionalities of a social media for school users, i.e. teachers, students, school management team. In the year of 2013, the SSN was implemented and equipped with a standardized document for software quality assurance. However, a quality control to ensure whether the software is developed according to its specification is not yet implemented. This situation may lead to several problems, e.g.: 1) a software program that did not meet its requirements; 2) lack of understanding toward the software quality specification that is important to ensure its implementation; 3) the vulnerability of the software program. Therefore, software quality control is necessary to improve the quality of SSN based on the requirement specification. The development of software quality control comprises of three steps, i.e. the analysis of the infrastructure for the software quality assurance, the analysis of the requirements for the software quality control based on ISO 25030 focusing on the Software Quality Requirements, and the documentation of the software quality control and its verification. The output of this study is a documentation of software quality control that includes four types of documents: guidance (1 document), policy (1 document), procedures (8 documents) and checklists (8 documents).
\end{abstract}

\section{Abstrak}

School Social Network (SSN) merupakan perangkat lunak untuk sekolah yang digunakan sebagai media interaksi antara guru, murid, dan pihak manajemen sekolah. Pada tahun 2013, pengembangan perangkat lunak telah melalui tahap uji coba dan telah dilengkapi dengan dokumentasi penjaminan kualitas sesuai dengan standar, Namun seperangkat kontrol untuk kepastian bahwa produk perangkat lunak telah memenuhi tujuan spesifikasi kebutuhan yang berkualitas, masih belum diterapkan. Kontrol kualitas belum dilakukan sehingga memungkinkan terjadinya permasalahan, mencakup: 1) ketidaksesuaian perangkat lunak yang dihasilkan dengan kebutuhan pengguna; 2) kurangnya pemahaman akan persyaratan kualitas perangkat lunak yang sangat penting untuk penggunaan sistem; 3) rentannya potensi terjadinya kesalahan pada perangkat lunak. Untuk mengatasi permasalahan tersebut, dibutuhkan sebuah perangkat kontrol kualitas yang dapat digunakan agar aplikasi SSN berkualitas sesuai dengan spesifikasi kebutuhannya. Pembuatan perangkat kontrol kualitas berangkat dari pendefinisian kontrol terhadap kualitas yang sesuai dengan standar ISO 25030 berfokus pada Software Quality Requirements dan menyesuaikan dengan studi kasus SSN. Kemudian perangkat kontrol kualitas disusun sesuai dengan kebutuhan dan verifikasi terhadap standar. Output dari penyusunan perangkat kontrol kualitas ini yaitu berupa dokumen yang terdiri dari 1 dokumen panduan, 1 dokumen kebijakan, 8 dokumen prosedur, dan 8 dokumen checklist.

Kata kunci: kontrol, kualitas, perangkat lunak, ISO 25030, school social network

\section{PENDAHULUAN}

Kualitas perangkat lunak merupakan seperangkat karakteristik terukur yang mendefinisikan persyaratan kebutuhan perangkat lunak yang berkualitas dari sudut pandang pembeli, pengguna, dan pengelola (Clapp, Judith A.; Stanten, Saul F.; 2011). Persyaratan kualitas tersebut penting untuk dikontrol agar perangkat lunak yang dihasilkan dapat berkualitas, dalam hal ini, memenuhi persyaratan kebutuhannya. Kontrol kualitas (software quality control) memastikan bahwa perangkat lunak yang dibangun tidak mengalami permasalahan seperti: fungsi yang salah dalam program maupun fungsi yang tidak sesuai dengan kebutuhan (Tian, 2005). Hal ini dapat menyebabkan tidak terpenuhinya ekspektasi perangkat lunak yang berkualitas, atau dalam beberapa kasus, perangkat lunak yang telah 
dikembangkan namun tidak dapat digunakan karena cacat/gagal produk (Horch, 2003).

Penelitian ini berfokus pada kontrol kualitas dari perangkat lunak dengan menggunakan studi kasus aplikasi School Social Network (SSN). Perangkat lunak ini merupakan aplikasi jejaring sosial - sebagai bagian dari bagian dari aplikasi Sistem Layanan Informasi Manajemen Sekolah Plus (SLIMS+) - yang dibuat sebagai media interaksi antara guru, murid, dan pihak manajemen sekolah. Pada penelitian sebelumnya, Nurkasanah (Nurkasanah, 2013) telah menyusun perangkat penjaminan kualitas perangkat lunak untuk aplikasi SSN. Namun, perangkat kontrol kualitas perangkat lunak, masih belum dibuat sehingga kepastian produk perangkat lunak yang dihasilkan dalam memenuhi kebutuhan belum diidentifikasikan sehingga berpotensi menimbulkan berbagai macam permasalahan berikut.

1) Permasalahan yang berkaitan dengan perangkat lunak yang dihasilkan tidak sesuai dengan kebutuhan.

Permasalahan dapat ditimbulkan karena tidak tersedianya kontrol terhadap dokumentasi spesifikasi kebutuhan yang telah dibuat. Hal ini membuka peluang terjadinya penyimpangan kebutuhan yang dispesifikasikan di awal pengembangan dengan perangkat lunak yang dihasilkan. Pada saat penelitian ini disusun (tahun 2013), aplikasi SSN telah dikembangkan dan sampai pada tahap uji coba, namun belum menerapkan kontrol terhadap dokumentasi spesifikasi kebutuhannya. Perangkat kontrol kualitas memberikan sarana untuk mengatasi masalah-masalah yang harus diselesaikan di saat pengembangan untuk memastikan bahwa perangkat lunak siap untuk di sampaikan ke klien.

2) Permasalahan yang berkaitan dengan pemenuhan terhadap persyaratan kebutuhan kualitas perangkat lunak (software quality requirements).

Persyaratan kebutuhan kualitas dari perangkat lunak perlu dipahami dari sudut pandang pemangku kepentingan (stakeholder), seperti: pembeli, pengguna maupun pengelola. Persyaratan kualitas tersebut perlu dikontrol pemenuhannya untuk meminimalisir terjadinya penyimpangan kebutuhan, maupun meminimalisir cacat atau kegagalan pada perangkat lunak. Aplikasi SSN belum mengakomodasi perangkat kontrol kualitas yang dapat digunakan untuk kepastian pemenuhan persyaratan kebutuhan perangkat lunak (software quality requirements).
3) Permasalahan yang berkaitan dengan kerentanan perangkat lunak.

Kesalahan tidak hanya terjadi pada fungsi yang salah pada program, namun juga kurangnya pemahaman terhadap kerentanan perangkat lunak (Quality Market: Design and Field Study of Prediction Market for Software Quality Control,, 2011). Kesalahan pada program dapat berupa bug sehingga fitur pada perangkat lunak tidak dapat dijalankan. Sedangkan kerentanan perangkat lunak dapat mencakup aspek keamanan seperti kerentanan terhadap virus, maupun aspek kompatibilitas seperti kompatibel dengan sistem operasi yang digunakan. Aplikasi SSN belum mengakomodasi perangkat kontrol kualitas yang dapat digunakan untuk pendeteksian kemungkinan kerentanan perangkat lunak. Perangkat kontrol kualitas dapat mengindari kemungkinan terjadinya cacat atau kegagalan pada perangkat lunak setelah diimplementasikan (after delivery).

Dengan mempertimbangkan permasalahan tersebut, penelitian ini berfokus kepada penyusunan perangkat kontrol kualitas pada aplikasi SSN. Tujuan dari penelitian ini adalah tersusunnya perangkat kontrol kualitas yang dapat memastikan pemenuhan persyaratan kebutuhan kualitas perangkat lunak (software quality requirements) berdasarkan standar ISO 25030. Hasil penelitian ini diharapkan membantu pengembang untuk melakukan kontrol kualitas aplikasi SSN sehingga dapat: 1) memenuhi kebutuhan pemangku kepentingan, 2) memastikan aplikasi yang dihasilkan tidak cacat/gagal produk.

\subsection{Kontrol Kualitas Perangkat Lunak}

Kontrol kualitas perangkat lunak atau Software Quality Control (SQC) adalah seperangkat metode yang digunakan untuk mencapai tujuan kualitas pada proyek tertentu dan untuk terus meningkatkan proses sehingga tingkat kualitas yang lebih tinggi dapat dicapai dengan biaya yang lebih rendah. Kontrol kualitas adalah proses dan metode yang digunakan untuk memonitor pekerjaan dan mengamati apakah persyaratan terpenuhi (Wagner, 2013).

Kontrol kualitas merupakan bagian dari penjaminan kualitas perangkat lunak atau Software Quality Assurance (SQA), yang didefinisikan sebagai berikut (Galin, 2003):

1. Pola aktivitas yang terencana dan sistematis untuk menyediakan produk perangkat lunak yang memenuhi kebutuhan teknis.

2. Serangkaian aktivitas yang direncanakan untuk mengevaluasi proses dimana perangkat lunak dibangun atau dikembangkan. 
Tabel 1. Keterkaitan $S Q A$ dan $S Q C$

\begin{tabular}{|c|c|c|}
\hline Kriteria & SQA & SQC \\
\hline Definisi & $\begin{array}{l}\checkmark \text { Serangkaian kegiatan untuk menjamin } \\
\text { kualitas dalam proses rekayasa perangkat } \\
\text { lunak (yang pada akhirnya menghasilkan } \\
\text { kualitas produk perangkat lunak). } \\
\checkmark \text { Kegiatan membangun dan mengevaluasi } \\
\text { proses yang menghasilkan produk. }\end{array}$ & $\begin{array}{l}\checkmark \text { Serangkaian kegiatan untuk } \\
\text { menjamin kualitas produk } \\
\text { perangkat lunak. } \\
\checkmark \text { Kegiatan berfokus pada } \\
\text { identifikasi cacat pada produk } \\
\text { yang sebenarnya dihasilkan. }\end{array}$ \\
\hline Fokus & Proses & Produk \\
\hline Orientasi & Pencegahan & Deteksi \\
\hline $\begin{array}{l}\text { Breadth } \\
\text { (kontaks } \\
\text { cakupan) }\end{array}$ & Organisasi & Produk/proyek tertentu \\
\hline $\begin{array}{l}\text { Scope (ruang } \\
\text { lingkup) }\end{array}$ & $\begin{array}{l}\text { Berkaitan dengan semua produk yang akan } \\
\text { dibuat oleh suatu proses }\end{array}$ & Berkaitan dengan produk tertentu \\
\hline Aktivitas & $\begin{array}{l}\text { - Pendefinisian proses dan implementasi } \\
\text { - Audit } \\
\text { - Pelatihan }\end{array}$ & $\begin{array}{l}\text { - Review } \\
\text { - Pengujian }\end{array}$ \\
\hline
\end{tabular}

Perbedaan mendasar dari kedua konsep tersebut adalah kontrol kualitas (SQC) berfokus kepada produk yang dihasilkan, sementara penjaminan kualitas perangkat lunak (SQA) fokus terhadap proses. Tabel 1 menggambarkan perbedaan antara SQA dan SQC dilihat dari kriteria: definisi, fokus, orientasi, breadth, scope, maupun aktivitas.

\subsection{Standar ISO 25030}

ISO/IEC 25030 (Software engineering-Software product Quality Requirements and Evaluation (SQuaRE)) memberikan rincian tentang persyaratan perencanaan dan manajemen terkait dengan persyaratan kualitas perangkat lunak dan evaluasinya (ISO/IEC, 2007). Standar ini bertujuan untuk meningkatkan kualitas persyaratan kualitas perangkat lunak (software quality requirements). Hal ini dilakukan dengan memberikan persyaratan dan rekomendasi untuk penggalian kebutuhan, dan bimbingan untuk proses yang digunakan untuk menentukan dan menganalisis penggalian kebutuhan.

\subsection{Aplikasi SSN}

School Social Network (SSN) merupakan aplikasi bagian dari SLIMS+ atau Sistem Layanan Informasi Manajemen Sekolah Plus (Nurkasanah, 2013). SLIMS+ adalah aplikasi yang dibangun untuk memanajemen dan memberikan layanan informasi kepada manajerial, guru, karyawan, siswa, dan orang tua siswa.terkait hal - hal yang berhubungan dengan sekolah. SSN dikembangkan dalam 2 (dua) versi, yaitu versi aplikasi berbasis web dan mobile. Manfaat yang diharapkan dari aplikasi SSN adalah:

a) Penggunaan aplikasi yang termonitor dan positif

b) Mendukung proses belajar mengajar di sekolah c) Inovasi dan melayani dengan baik

d) Sebagai media marketing rekanan

\section{METODOLOGI}

Pada bagian ini akan dipaparkan metode yang digunakan dalam penelitian yang mencakup 5 (lima) tahap sebagai berikut.

\subsection{Pengumpulan Data}

Wawancara dan diskusi dengan pihak pengembang aplikasi SSN untuk mengetahui kondisi terkini pengembangan aplikasi SSN. Hal tersebut mencakup: 1) informasi umum, seperti tujuan pengembangan, pihak-pihak yang terkait dengan proses pengembangan; maupun 2) informasi khusus, seperti: informasi mengenai penggalian kebutuhan. Observasi juga dilakukan dengan melakukan peninjauan langsung pada dokumen penjaminan kualitas yang telah dibuat sebelumnya (Nurkasanah, 2013), serta peninjauan pada dokumen aplikasi SSN dari pihak pengembang untuk mengetahui proses eksekusi pengembangan perangkat lunak. Hasil akhir dari tahap ini adalah potret kondisi terkini mengenai pengembangan aplikasi SSN beserta dokumentasi penjaminan kualitasnya.

\subsection{Analisis Infrastruktur Penjaminan Kualitas}

Analisis infrastruktur penjaminan kebutuhan ini mengacu pada perangkat penjaminan kualitas aplikasi SSN yang dilakukan pada penelitian Nurkasanah (Nurkasanah, 2013). Penjaminan kebutuhan yang dilakukan oleh penelitian sebelumnya tersebut mencakup keseluruhan siklus hidup pengembangan aplikasi SSN, yaitu: 1) penggalian kebutuhan, 2) desain, 3) koding, dan 4) uji coba. Adapun fokus dari penelitian ini adalah penyusunan kontrol kualitas untuk tahap 
penggalian kebutuhan. Hasil akhir dari tahap ini adalah infrastruktur yang dipilih dari tahap penggalian kebutuhan dalam dokumen penjaminan kebutuhan, mencakup: tugas penjaminan kualitas dan aktivitas penjaminan kualitas, yang menjadi masukan (input) dalam pembuatan perangkat kontrol kualitas.

\subsection{Persiapan Perangkat Kontrol Kualitas}

Setelah diketahui potret terkini pengembangan aplikasi SSN dan infrastruktur penjaminan kualitas yang terkait, selanjutnya dilakukan pemilihan indikator standar quality requirements berdasarkan ISO 25030 manakah yang sesuai untuk pengembangan aplikasi SSN. Hasil akhir dari tahap ini adalah pemilihan indikator yang sesuai dalam konteks penyusunan perangkat kontrol kualitas yang berfokus pada tahap penggalian kebutuhan, yaitu :

- Software Quality in use Requirements

- External software quality requirements

- Internal software quality requirements

\subsection{Pembuatan Perangkat Kontrol Kualitas}

Perangkat kontrol kualitas disusun berdasarkan indikator yang dipilih dalam konteks software quality requirements. Hasil akhir yang dihasilkan merupakan perangkat kontrol kualitas yang mencakup:

- Panduan

- Kebijakan

- Prosedur

- Checklist

Perangkat tersebut akan menjamin tugas - tugas perangkat kontrol kualitas perangkat lunak dalam proses pengembangan aplikasi SSN.

\subsection{Verifikasi Perangkat Kontrol Kualitas}

Metode yang digunakan dalam verifikasi menggunakan checklist untuk memastikan bahwa perangkat yang sudah dibuat sudah sesuai dengan Standar ISO 25030. Verifikasi juga dilakukan dengan melihat pemenuhan infrastruktur penjaminan kualitas, yang mencakup tugas dan aktivitas penjaminan kualitas, terhadap tugas dan aktivitas dalam Standar ISO 25030.

\section{HASIL DAN PEMBAHASAN}

Tugas dari kontrol kualitas yang didefinisikan dalam ISO 25030 mendefinisikan keseluruhan kebutuhan kualitas perangkat lunak. Namun fokus penyusunan kontrol kualitas pada penelitian ini dibatasi pada fase penggalian kebutuhan proyek pengembangan perangkat lunak - dalam hal ini aplikasi SSN, sehingga tugas kontrol kualitas yang diambil dari ISO 25030 hanya yang terkait dengan fase tersebut.

Pada tahap awal, analisis infrastruktur penjaminan kualitas untuk aplikasi SSN dalam penyusunan perangkat kontrol kualitas dilakukan untuk mengetahui aktivitas dalam penjaminan kualitas dalam fase penggalian kebutuhan, dan dokumen yang terkait dalam fase tersebut. Hasil analisis tersebut menghasilkan 8 (delapan) aktivitas dalam penjaminan kualitas untuk fase penggalian kebutuhan yang akan dijadikan masukan dalam penyusunan perangkat kontrol kualitas dalam penelitian ini. Fase tersebut memiliki dokumen penjaminan kualitas seperti dipaparkan lebih detil dalam Tabel 2.

Tabel 2. Analisis infrastruktur penjaminan kualitas menghasilkan delapan aktivitas dalam penjaminan kualitas yang akan difokuskan pada penelitian ini

\begin{tabular}{lll}
\hline \multicolumn{1}{c}{ Kualitas } & & Dokumen Penjaminan Kualitas \\
\hline Verifikasi bahwa partisipan & - Formulir & 1. [FM-02 R00] Diskusi Peran Tanggung Jawab \\
yang berhak telah terlibat dalam & - Chekclist & Elemen Pengembangan SSN \\
penentuan kebutuhan sistem. & - Panduan & 2. [CH-01 R00] Evaluasi Penggalian Kebutuhan \\
& - Template & Sistem SSN \\
& - Checklist & 3. [PA-01 R00] Penjaminan Kualitas \\
& & Pengembangan Aplikasi School Social Network \\
& & (PKPA-SSN) \\
& & 4. [TE-01 R00] Spesifikasi Kebutuhan Sistem dan \\
& & Perangkat Lunak School Social Network \\
Verifikasi bahwa alokasi sistem & (SKSPL-SSN-SSN) \\
telah didefinisikan dan & - Panduan & 5. [CH-01 R00] Evaluasi Penggalian Kebutuhan \\
disepakati, diikuti dan & SSN \\
didokumentasikan. & - Formulir & Pengembangan Aplikasi School Social Network \\
& - Template & (PKPA-SSN) \\
& - Kebijakan & 2. [FM-03 R00] Diskusi Kebutuhan Sistem SSN \\
& - Checklist & 3. [TE-01 R00] Spesifikasi Kebutuhan Sistem dan \\
& & Perangkat Lunak School Social Network \\
& & (SKSPL-SSN-SSN) \\
\hline
\end{tabular}




\begin{tabular}{|c|c|c|}
\hline \multirow[t]{2}{*}{$\begin{array}{c}\text { Aktivitas dalam Penjaminan } \\
\text { Kualitas }\end{array}$} & \multirow{2}{*}{\multicolumn{2}{|c|}{$\begin{array}{l}\text { Dokumen Penjaminan Kualitas } \\
\text { 4. [KE-01 R00]Fase EksplorasiSSN } \\
\text { 5. [CH-01 R00] Evaluasi Penggalian Kebutuhan } \\
\text { SSN }\end{array}$}} \\
\hline & & \\
\hline $\begin{array}{l}\text { Verifikasi bahwa perubahan } \\
\text { pada kebutuhan sistem telah } \\
\text { teridentifikasi, tereview, dan } \\
\text { tertelusuri. }\end{array}$ & $\begin{array}{l}\text { - Template } \\
\text { - Checklist } \\
\text { - Panduan }\end{array}$ & $\begin{array}{l}\text { 1. [TE-01 R00] Spesifikasi Kebutuhan Sistem dan } \\
\text { Perangkat Lunak School Social Network } \\
\text { (SKSPL-SSN-SSN) } \\
\text { 2. [CH-01 R00] Evaluasi Penggalian Kebutuhan } \\
\text { SSN } \\
\text { 3. [PA-01 R00] Penjaminan Kualitas } \\
\text { Pengembangan Aplikasi School Social Network } \\
\text { (PKPA-SSN) }\end{array}$ \\
\hline $\begin{array}{l}\text { Verifikasi bahwa alokasi sistem } \\
\text { yang berpotensi bermasalah atau } \\
\text { yang sedang bermasalah telah di } \\
\text { review oleh pihak yang } \\
\text { bertanggungjawab di dalamnya. }\end{array}$ & $\begin{array}{l}\text { - Formulir } \\
\text { - Panduan } \\
\text { - Checklist }\end{array}$ & $\begin{array}{l}\text { 1. [FM-04 R00] Catatan Permasalahan Sistem SSN } \\
\text { 2. [PA-01 R00] Penjaminan Kualitas } \\
\text { Pengembangan Aplikasi School Social Network } \\
\text { (PKPA-SSN) } \\
\text { 3. [CH-01 R00] Evaluasi Penggalian Kebutuhan } \\
\text { SSN }\end{array}$ \\
\hline $\begin{array}{l}\text { Verifikasi bahwa kebutuhan } \\
\text { perangkat lunak didefinisikan } \\
\text { dan didokumentasikan sesuai } \\
\text { dengan prosedur. }\end{array}$ & $\begin{array}{l}\text { - Formulir } \\
\text { - Template } \\
\text { - Kebijakan } \\
\text { - Checklist } \\
\text { - Panduan }\end{array}$ & $\begin{array}{l}\text { 1. [FM-01 R00] Stori Kebutuhan Fungsional SSN } \\
\text { 2. [TE-01 R00] Spesifikasi Kebutuhan Sistem dan } \\
\text { Perangkat Lunak School Social Network } \\
\text { (SKSPL-SSN-SSN) } \\
\text { 3. [KE-01 R00] Fase Eksplorasi SSN } \\
\text { 4. [CH-02 R00] Evaluasi Penggalian Kebutuhan } \\
\text { Perangkat Lunak SSN } \\
\text { 5. [PA-01 R00] Penjaminan Kualitas } \\
\text { Pengembangan Aplikasi School Social Network } \\
\text { (PKPA-SSN) }\end{array}$ \\
\hline $\begin{array}{l}\text { Verifikasi bahwa tindakan } \\
\text { perubahan dilaksanakan sesuai } \\
\text { dengan prosedur. }\end{array}$ & $\begin{array}{l}\text { - Panduan } \\
\text { - Template } \\
\text { - Checklist }\end{array}$ & $\begin{array}{l}\text { 1. [PA-01 R00] Penjaminan Kualitas } \\
\text { Pengembangan Aplikasi School Social Network } \\
\text { (PKPA-SSN) } \\
\text { 2. [TE-01 R00] Spesifikasi } \\
\text { 3. Kebutuhan Sistem dan Perangkat Lunak School } \\
\text { Social Network (SKSPL-SSN-SSN) } \\
\text { 4. [CH-02 R00] Evaluasi Penggalian Kebutuhan } \\
\text { Perangkat Lunak SSN }\end{array}$ \\
\hline $\begin{array}{l}\text { Verifikasi bahwa prioritasisasi } \\
\text { fitur, estimasi waktu dan } \\
\text { penanggungjawab pengerjaan } \\
\text { tiap fitur telah dilakukan dan } \\
\text { didokumentasikan. }\end{array}$ & $\begin{array}{l}\text { - Kebijakan } \\
\text { - Formulir } \\
\text { - Template } \\
\text { - Panduan } \\
\text { - Checklist }\end{array}$ & $\begin{array}{l}\text { 1. [FM-01 R00] Stori Kebutuhan Fungsional SSN } \\
\text { 2. [FM-05 R00] Fase Perencanaan SSN. } \\
\text { 3. [TE-01 R00] Spesifikasi Kebutuhan Sistem dan } \\
\text { Perangkat Lunak School Social Network } \\
\text { (SKSPL-SSN-SSN) } \\
\text { 4. [PA-01 R00] Penjaminan Kualitas } \\
\text { Pengembangan Aplikasi School Social Network } \\
\text { (PKPA-SSN) } \\
\text { 5. [CH-03 R00] Evaluasi Fase Perencanaan SSN } \\
\text { 1. [KE-02 R00] Fase Perencanaan SSN } \\
\text { 2. [FM-05 R00] Fase Perencanaan SSN. } \\
\text { 3. [TE-01 R00] Spesifikasi Kebutuhan Sistem dan } \\
\text { Perangkat Lunak School Social Network } \\
\text { (SKSPL-SSN-SSN) } \\
\text { 4.[PA-01 R00] Penjaminan Kualitas } \\
\text { Pengembangan Aplikasi School Social Network } \\
\text { (PKPA-SSN) } \\
\text { 5. [CH-03 R00] Evaluasi Fase Perencanaan SSN }\end{array}$ \\
\hline
\end{tabular}


Pada tahap selanjutnya, dilakukan persiapan perangkat kontrol kualitas dengan melakukan pemetaan antara tugas dan aktivitas dalam standar ISO 25030 terhadap tugas dan aktivitas dalam dokumen penjaminan kualitas pengembangan SSN. Tabel 3 menggambarkan bagaimana perangkat kontrol kualitas dapat disusun sesuai standar ISO 25030 dan memenuhi penjaminan kualitas pengembangan SSN. Dari hasil penyesuaian pemetaan tersebut, didapatkan 5 (lima) aktivitas dalam Standar ISO 25030 yang sesuai dengan aktivitas dalam penjaminan kualitas aplikasi SSN. Berdasarkan hasil analisis infrastruktur penjaminan kualitas dan hasil persiapan perangkat kontrol kualitas, perangkat kontrol kualitas dapat disusun berdasarkan aktivitas dalam standar ISO 25030. Tabel 4 berikut memaparkan ringkasan dokumen kontrol yang dihasilkan dalam penyusunan perangkat kontrol kualitas yang memenuhi standar ISO 25030.

Pada tahapan selanjutnya, verifikasi dilakukan terhadap penyusunan perangkat kontrol kualitas. Tabel 5 berikut menyajikan hasil verifikasi doku- men kontrol kualitas terhadap standar ISO 25030. Dari hasil verifikasi tersebut didapatkan bahwa hanya 5 (lima) aktivitas dalam penjaminan kualitas aplikasi SSN yang dapat memenuhi ISO 25030. Dengan demikian, perangkat kontrol kualitas yang dihasilkan melalui penelitian ini, memenuhi sekitar $41 \%$ (atau 5 dari 12 aktivitas) dari aktivitas dalam ISO 25030. Berdasarkan Tabel 5 tersebut, didapatkan hasil verifikasi dokumen kontrol kualitas yang memastikan apakah dokumentasi penyusunan perangkat kontrol kualitas ini telah memenuhi standar kontrol kualitas, dalam hal ini ISO 25030. Selain itu, dari penyusunan perangkat kontrol kualitas, perlu dikorelasikan antara hasil penyusunan kontrol kualitas dengan karakteristik kualitas (Clapp, Judith A.; Stanten, Saul F.; 2011). Hal ini disebabkan karena sebagian faktor-faktor yang terdapat pada karakteristik kualitas memberikan kontribusi untuk mencapai kualitas dari perangkat lunak. Korelasi antara hasil kontrol kualitas pengembangan aplikasi SSN dengan faktor kualitas seperti terlihat pada Tabel 6 .

Tabel 3. Pemetaan tugas dan aktivitas dalam ISO 25030 dengan tugas dan aktivitas dalam dokumen penjaminan kualitas dijadikan masukan dalam penyusunan perangkat kontrol kualitas

\begin{tabular}{|c|c|c|c|c|}
\hline \multicolumn{2}{|c|}{ Standar ISO 25030} & \multicolumn{2}{|c|}{$\begin{array}{l}\text { Dokumen Penjaminan Kualitas } \\
\text { Pengembangan Aplikasi SSN }\end{array}$} & \multirow{2}{*}{$\begin{array}{c}\text { Keterangan Hasil Kontrol } \\
\text { Kualitas }\end{array}$} \\
\hline $\begin{array}{c}\text { Tugas } \\
\text { Standar } \\
\text { ISO 25030 }\end{array}$ & $\begin{array}{c}\text { Aktivitas dalam } \\
\text { Standar ISO } \\
25030\end{array}$ & $\begin{array}{c}\text { Tugas } \\
\text { Penjaminan } \\
\text { Kualitas }\end{array}$ & $\begin{array}{c}\text { Aktivitas } \\
\text { Penjaminan } \\
\text { Kualitas }\end{array}$ & \\
\hline \multirow[t]{3}{*}{$\begin{array}{l}\text { Stake- } \\
\text { holder } \\
\text { quality } \\
\text { requi- } \\
\text { rements }\end{array}$} & $\begin{array}{l}\text { - Verifikasi bahwa } \\
\text { semua pihak yang } \\
\text { terkait harus } \\
\text { terdaftar } \\
\text { - Verifikasi peran } \\
\text { dan kepentingan } \\
\text { stakeholder yang } \\
\text { terdaftar harus } \\
\text { didokumentasikan. }\end{array}$ & $\begin{array}{l}\text { Evaluasi } \\
\text { Kebutuhan } \\
\text { Sistem }\end{array}$ & $\begin{array}{l}\text { Verifikasi } \\
\text { bahwa partisipan } \\
\text { yang berhak telah } \\
\text { terlibat dalam } \\
\text { kebutuhan } \\
\text { penentuan sistem }\end{array}$ & $\begin{array}{l}\text { Pada bagian ini, aktivitas yang } \\
\text { terdapat dalam penjaminan } \\
\text { kualitas telah sesuai dengan ISO } \\
\text { 25030, namun masih belum } \\
\text { menjelaskan semua tentang } \\
\text { kebutuhan sistem. Kebutuhan } \\
\text { sistem dalam penjaminan } \\
\text { kualitas termasuk dalam } \\
\text { application software } \\
\text { requirements. }\end{array}$ \\
\hline & $\begin{array}{l}\text { Verifikasi bahwa } \\
\text { analisa resiko telah } \\
\text { diterapkan untuk } \\
\text { memastikan } \\
\text { cakupan aspek } \\
\text { kritis }\end{array}$ & & $\begin{array}{l}\text { Verifikasi bahwa } \\
\text { alokasi sistem yang } \\
\text { berpotensi } \\
\text { bermasalah atau } \\
\text { yang sedang } \\
\text { bermasalah direview } \\
\text { oleh pihak yang } \\
\text { bertanggungjawab }\end{array}$ & $\begin{array}{l}\text { Pada bagian ini, aktivitas pada } \\
\text { penjaminan kualitas tentang } \\
\text { penggalian kebutuhan sistem } \\
\text { sesuai dengan ISO } 25030 . \\
\text { Karena pada penjaminan } \\
\text { kualitas telah megidentifikasi } \\
\text { analisa resiko penggalian } \\
\text { kebutuhan sistem. }\end{array}$ \\
\hline & $\begin{array}{l}\text { Verifikasi bahwa } \\
\text { penggalian } \\
\text { kebutuhan } \\
\text { diidentifikasi untuk } \\
\text { dapat menghasilkan } \\
\text { kualitas kebutuhan } \\
\text { stakeholder }\end{array}$ & & $\begin{array}{l}\text { Verifikasi bahwa } \\
\text { alokasi sistem } \\
\text { didefinisikan, } \\
\text { didokumentasikan, } \\
\text { disepakati }\end{array}$ & $\begin{array}{l}\text { Pada bagian ini, aktivitas yang } \\
\text { terdapat dalam penjaminan } \\
\text { kualitas telah sesuai dengan } \\
\text { ISO 25030, karena dalam } \\
\text { penjaminan kualitas telah } \\
\text { mengidentifikasi kebutuhan } \\
\text { yang mencakup tentang } \\
\text { kebutuhan stakeholder. }\end{array}$ \\
\hline
\end{tabular}




\begin{tabular}{|c|c|c|c|c|}
\hline \multicolumn{2}{|c|}{ Standar ISO 25030} & \multicolumn{2}{|c|}{$\begin{array}{l}\text { Dokumen Penjaminan Kualitas } \\
\text { Pengembangan Aplikasi SSN }\end{array}$} & \multirow{2}{*}{$\begin{array}{c}\text { Keterangan Hasil Kontrol } \\
\text { Kualitas }\end{array}$} \\
\hline \multirow[t]{5}{*}{$\begin{array}{c}\text { Tugas } \\
\text { Standar } \\
\text { ISO 25030 } \\
\end{array}$} & $\begin{array}{c}\text { Aktivitas dalam } \\
\text { Standar ISO } \\
25030\end{array}$ & $\begin{array}{c}\text { Tugas } \\
\text { Penjaminan } \\
\text { Kualitas }\end{array}$ & $\begin{array}{c}\text { Aktivitas } \\
\text { Penjaminan } \\
\text { Kualitas }\end{array}$ & \\
\hline & & $\begin{array}{l}\text { Evaluasi } \\
\text { Kebutuhan } \\
\text { Perangkat } \\
\text { Lunak }\end{array}$ & $\begin{array}{l}\text { Verifikasi bahwa } \\
\text { kebutuhan perangkat } \\
\text { lunak dilakukan } \\
\text { sesuai dengan } \\
\text { prosedur }\end{array}$ & $\begin{array}{l}\text { Pada bagian ini, aktivitas yang } \\
\text { terdapat dalam penjaminan } \\
\text { kualitas telah sesuai dengan } \\
\text { ISO 25030, karena dalam } \\
\text { penjaminan kualitas telah } \\
\text { mengidentifikasi kebutuhan } \\
\text { yang mencakup tentang } \\
\text { kebutuhan stakeholder. } \\
\text { Pada bagian ini, aktivitas yang } \\
\text { terdapat dalam penjaminan } \\
\text { kualitas telah sesuai dengan } \\
\text { ISO 25030, karena dalam } \\
\text { penjaminan kualitas telah } \\
\text { mengidentifikasi kebutuhan } \\
\text { yang mencakup tentang } \\
\text { kebutuhan stakeholder. }\end{array}$ \\
\hline & & & $\begin{array}{l}\text { Verifikasi bahwa } \\
\text { tindakan perubahan } \\
\text { kebutuhan perangkat } \\
\text { lunak sesuai dengan } \\
\text { prosedur }\end{array}$ & $\begin{array}{l}\text { Pada bagian ini, aktivitas yang } \\
\text { terdapat dalam penjaminan } \\
\text { kualitas telah sesuai dengan } \\
\text { ISO 25030, karena dalam } \\
\text { penjaminan kualitas telah } \\
\text { mengidentifikasi kebutuhan } \\
\text { yang mencakup tentang } \\
\text { kebutuhan stakeholder. }\end{array}$ \\
\hline & $\begin{array}{l}\text { Model kualitas } \\
\text { dapat diterapkan } \\
\text { dalam bentuk } \\
\text { checklist untuk } \\
\text { memastikan } \\
\text { cakupan semua } \\
\text { aspek kualitas. }\end{array}$ & $\begin{array}{l}\text { Fase Peren- } \\
\text { canaan }\end{array}$ & $\begin{array}{l}\text { Prosedur verifikasi } \\
\text { prioritasi-sasi fitur, } \\
\text { estimasi waktu, } \\
\text { penanggung jawab } \\
\text { pengerjaan telah } \\
\text { didokumentasikan }\end{array}$ & $\begin{array}{l}\text { Pada bagian ini, aktivitas yang } \\
\text { terdapat dalam penjaminan } \\
\text { kualitas telah merencanakan } \\
\text { bagaimana untuk memastikan } \\
\text { cakupan kualitas dari } \\
\text { pengembangan aplikasi SSN. }\end{array}$ \\
\hline & $\begin{array}{l}\text { Model kualitas } \\
\text { dapat diterapkan } \\
\text { dalam bentuk } \\
\text { checklist untuk } \\
\text { memastikan } \\
\text { cakupan semua } \\
\text { aspek kualitas. }\end{array}$ & & $\begin{array}{l}\text { Prosedur verifikasi } \\
\text { perubahan prioritasi- } \\
\text { sasi fitur, estimasi } \\
\text { waktu telah } \\
\text { didokumen-tasikan }\end{array}$ & $\begin{array}{l}\text { Pada bagian ini, aktivitas yang } \\
\text { terdapat dalam penjaminan } \\
\text { kualitas telah merencanakan } \\
\text { bagaimana untuk memastikan } \\
\text { cakupan kualitas dari } \\
\text { pengembangan aplikasi SSN. }\end{array}$ \\
\hline
\end{tabular}

Tabel 4. Hasil perangkat kontrol kualitas yang disusun telah disesuaikan dengan aktivitas dalam standar kontrol kualitas berdasarkan ISO 25030

\begin{tabular}{ll}
\hline $\begin{array}{l}\text { Aktivitas dalam Standar } \\
\text { ISO 25030 }\end{array}$ & \multicolumn{1}{c}{ Perangkat kontrol kualitas } \\
\hline $\begin{array}{l}\text { Verifikasi bahwa semua } \\
\text { pihak yang terkait harus }\end{array}$ & $\begin{array}{l}\text { Prosedur: [PR-01 R00] Prosedur verifikasi partisipan penggalian kebutuhan } \\
\text { sistem }\end{array}$ \\
& $\begin{array}{l}\text { Kebijakan: [KE-01 R00] Kontrol SSN } \\
\text { Checklist: [CH-01 R00] Checklist verifikasi partisipan penggalian kebutuhan } \\
\end{array}$ \\
& sistem
\end{tabular}




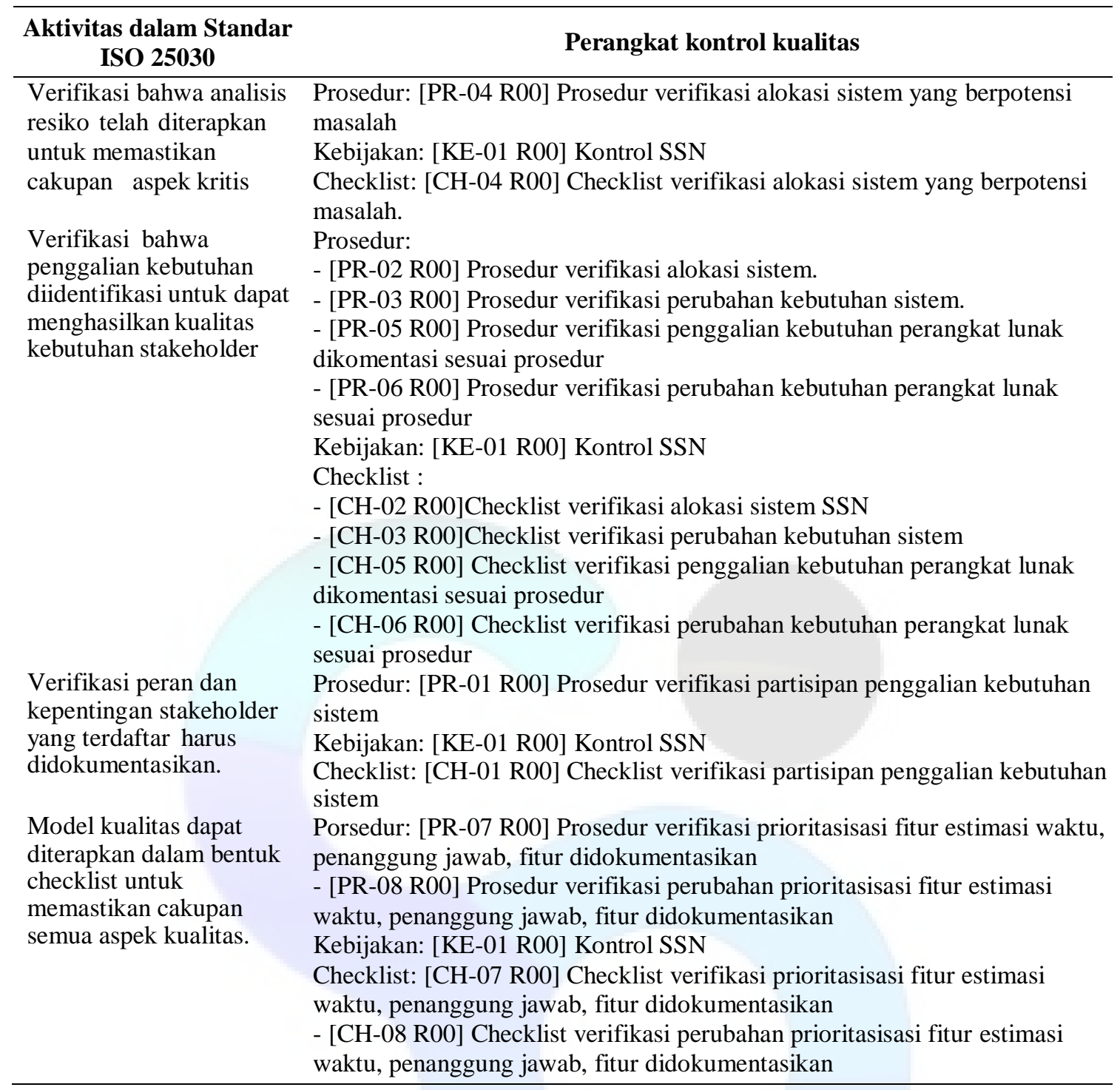

Tabel 5. Hasil verifikasi Perangkat Kontrol Kualitas menunjukkan bahwa tidak semua aktivitas dalam standar ISO 25030 terpenuhi dalam dokumen penjaminan kualitas aplikasi SSN

\begin{tabular}{lc}
\multicolumn{1}{c}{ Aktivitas dalam Standar ISO 25030 } & $\begin{array}{c}\text { Perangkat } \\
\text { Kontrol } \\
\text { Kualitas }\end{array}$ \\
\hline $\begin{array}{l}\text { Verifikasi bahwa semua pihak yang terkait harus terdaftar } \\
\text { Verifikasi bahwa analisis resiko telah diterapkan untuk memastikan cakupan aspek }\end{array}$ & $\mathrm{V}$ \\
kritis & $\mathrm{V}$ \\
$\begin{array}{l}\text { Verifikasi bahwa penggalian kebutuhan diidentifikasi untuk dapat menghasilkan kualitas } \\
\text { kebutuhan stakeholder }\end{array}$ & $\mathrm{X}$ \\
$\begin{array}{l}\text { Mengembangkan dan memelihara daftar ukuran kualitas yang telah ada. } \\
\text { Verifikasi bahwa top manajemen harus memastikan bahwa persyaratan customer }\end{array}$ & $\mathrm{X}$ \\
ditetapkan dan dipenuhi dengan tujuan untuk meningkatkan kepuasan customer. & $\mathrm{V}$ \\
Verifikasi peran dan kepentingan stakeholder yang terdaftar harus didokumentasikan. & $\mathrm{X}$ \\
Kebutuhan kualitas perangkat & \\
Lunak harus dapat ditelusuri dengan kebutuhan stakeholder. & $\mathrm{X}$ \\
Kebutuhan kualitas perangkat lunak harus dapat ditelusuri dengan kebutuhan stakeholder. \\
Model kualitas dapat diterapkan dalam bentuk checklist untuk memastikan cakupan semua \\
$\begin{array}{l}\text { aspek kualitas. } \\
\text { Nilai target untuk mengukur adalah nilai-nilai yang dapat diterima untuk memenuhi } \\
\text { kebutuhan kualitas perangkat lunak }\end{array}$ \\
$\begin{array}{l}\text { Profil operasional kebutuhan kualitas perangkat lunak harus ditetapkan bila relevan. } \\
\text { Dalam menentukan nilai target kebutuhan kualitas perangkat lunak harus didokumentasikan. }\end{array}$ \\
\hline
\end{tabular}


Tabel 6. Kaitan antara kontrol kualitas dan faktor kualitas

\begin{tabular}{|c|c|}
\hline Aktivitas dalam Kontrol Kualitas & $\begin{array}{l}\text { Faktor Kualitas berdasarkan Bowen (Clapp, Judith A.; } \\
\text { Stanten, Saul F.;, 2011) }\end{array}$ \\
\hline $\begin{array}{l}\text { Verifikasi bahwa partisipan yang } \\
\text { berhak telah terlibat dalam kebutuhan } \\
\text { penentuan sistem }\end{array}$ & $\begin{array}{l}\text { Effiency: Sejauh sehubungan dengan sumber daya yang } \\
\text { digunakan }\end{array}$ \\
\hline $\begin{array}{l}\text { Verifikasi bahwa alokasi sistem yang } \\
\text { berpotensi bermasalah atau yang }\end{array}$ & $\begin{array}{l}\text { - Effiency: Sejauh sehubungan dengan sumber daya yang } \\
\text { digunakan. }\end{array}$ \\
\hline $\begin{array}{l}\text { sedang bermasalah di riview oleh pihak } \\
\text { yang bertanggungjawab }\end{array}$ & $\begin{array}{l}\text { - Integrity: Sejauh mana perangkat lunak akan tampil tanpa } \\
\text { kegagalan }\end{array}$ \\
\hline $\begin{array}{l}\text { Verifikasi bahwa alokasi sistem } \\
\text { didefinisikan, didokumentasikan, } \\
\text { disepakati }\end{array}$ & $\begin{array}{l}\text { Correctness: Sejauh mana perangkat lunak sesuai dengan } \\
\text { spesifikasi dan standar. }\end{array}$ \\
\hline \multirow[t]{2}{*}{$\begin{array}{l}\text { Verifikasi bahwa perubahan kebutuhan } \\
\text { sistem telah teridentifikasi }\end{array}$} & $\begin{array}{l}\text { - Correctness: Sejauh mana perangkat lunak sesuai dengan } \\
\text { spesifikasi dan standar. }\end{array}$ \\
\hline & $\begin{array}{l}\text { Expandibility: Upaya sehubungan dengan meningkatkan } \\
\text { kemampuan perangkat lunak dan kinerja dengan } \\
\text { meningkatkan fungsi saat }\end{array}$ \\
\hline Verifikasi bahwa & Correctness: Sejauh mana \\
\hline $\begin{array}{l}\text { kebutuhan perangkat lunak dilakukan } \\
\text { sesuai dengan prosedur }\end{array}$ & perangkat lunak sesuai dengan spesifikasi dan standar. \\
\hline \multirow{3}{*}{$\begin{array}{l}\text { Verifikası bahwa tindakan perubahan } \\
\text { kebutuhan perangkat lunak sesuai } \\
\text { dengan prosedur }\end{array}$} & - Correctness: Sejauh mana perangkat lunak sesuai dengan \\
\hline & spesifikasi dan standar. \\
\hline & $\begin{array}{l}\text { Expandibility: upaya sehubungan dengan meningkatkan } \\
\text { kemampuan perangkat lunak dan kinerja dengan } \\
\text { meningkatkan fungsi saat ini atau dengan menambahkan } \\
\text { fungsi baru atau data. }\end{array}$ \\
\hline $\begin{array}{l}\text { Prosedur verifikasi prioritasisasi fitur, } \\
\text { estimasi waktu, penanggung jawab }\end{array}$ & $\begin{array}{l}\text { - Effiency: Sejauh sehubungan dengan sumber daya yang } \\
\text { digunakan. }\end{array}$ \\
\hline pengerjaan telah didokumentasikan & $\begin{array}{l}\text { - Verifiability: Upaya relatif untuk memverifikasi operasi } \\
\text { perangkat lunak tertentu dan kinerja. }\end{array}$ \\
\hline & $\begin{array}{l}\text { - Correctness: Sejauh mana perangkat lunak sesuai dengan } \\
\text { spesifikasi dan standar. }\end{array}$ \\
\hline \multirow{4}{*}{$\begin{array}{l}\text { Prosedur verifikasi perubahan } \\
\text { prioritasisasi fitur, estimasi waktu telah } \\
\text { didokumentasikan }\end{array}$} & $\begin{array}{l}\text { - Effiency: Sejauh sehubungan dengan sumber daya yang } \\
\text { digunakan. }\end{array}$ \\
\hline & $\begin{array}{l}\text { - Verifiability: Upaya relatif untuk memverifikasi operasi } \\
\text { perangkat lunak tertentu dan kinerja. }\end{array}$ \\
\hline & $\begin{array}{l}\text { - Correctness: Sejauh mana perangkat lunak sesuai dengan } \\
\text { spesifikasi dan standar. }\end{array}$ \\
\hline & $\begin{array}{l}\text { Expandibility: Upaya Sehubungan dengan meningkatkan } \\
\text { kemampuan perangkat lunak dan kinerja dengan } \\
\text { meningkatkan fungsi saat ini atau dengan menambahkan } \\
\text { fungsi baru atau data. }\end{array}$ \\
\hline
\end{tabular}

\section{SIMPULAN dan SARAN}

Penelitian ini menghasilkan perangkat kontrol kualitas untuk aplikasi SSN dengan rincian sebanyak: 1 (satu) dokumen panduan, 1 (satu) dokumen kebijakan, 8 (delapan) dokumen prosedur, dan 8 (delapan) dokumen checklist. Adapun temuan penting berkaitan dengan penggunaan standar ISO 25030 dalam penyusunan perangkat kontrol kualitas yang menyesuaikan dengan dokumen penjaminan kualitas aplikasi SSN, dipaparkan sebagai berikut. Temuan ini dapat dijadikan masukan untuk penelitian berikutnya yang berkaitan dengan kontrol kualitas perangkat lunak (software quality control).
Pemenuhan terhadap tugas dan aktivitas pada standar ISO 25030. Berdasarkan verifikasi penyusunan perangkat kontrol kualitas, sebanyak 7 (tujuh) aktivitas terkait penggalian kebutuhan pada standar ISO 25030 tidak terdefinisi pada dokumen penjaminan kualitas. Contoh dari aktivitas yang tidak terpenuhi pada dokumen penjaminan kualitas, yaitu verifikasi bahwa top manajemen harus memastikan bahwa persyaratan customer ditetapkan dan dipenuhi dengan tujuan untuk meningkatkan kepuasan customer. Dalam dokumen penjaminan kualitas pada tahap penggalian kebutuhan masih belum didefinisikan mengenai aktivitas tersebut seharusnya dilakukan. 
Pada penelitian berikutnya, perlu dipertimbangkan tugas dan aktivitas yang berkaitan khususnya yang berkaitan dengan persyaratan kebutuhan kualitas perangkat lunak (software quality requirements) berdasarkan standar ISO 25030. Pengembangan dokumen penjaminan kualitas dapat dilakukan untuk fase penggalian kebutuhan dengan mempertimbangkan seluruh tugas dan aktivitas dalam standar tersebut. Penelitian selanjutnya juga dapat mempertimbangkan pendefinisian tugas dan aktivitas berkaitan dengan persyaratan kebutuhan kualitas perangkat lunak terlebih dahulu sebelum penyusunan dokumen penjaminan kualitas.

Validasi perangkat kontrol kualitas. Aktivitas yang terdapat dalam standar ISO 25030 menjelaskan sampai pada kontrol kualitas produk, sedangkan penjaminan kualitas mencakup keseluruhan siklus pengembangan perangkat lunak. Perangkat kontrol kualitas tersebut disusun setelah dokumen penjaminan kualitas dibuat sementara perangkat lunak sudah mencapai tahap uji coba. Aktivitas penggalian kebutuhan telah dilakukan, dan aktivitas dalam penjaminan kualitas untuk fase penggalian kebutuhan sudah dilakukan. Namun karena tidak semua tugas dan aktivitas pada ISO 25030 untuk persyaratan kebutuhan kontrol kualitas (software quality requirements) belum terpenuhi, berdasarkan poin 1), maka perangkat kontrol kualitas yang disusun belum dapat divalidasi karena berpotensi mengubah dokumen penjaminan kualitas, dan mengubah aplikasi SSN yang telah dibangun untuk memenuhi seluruh praktik kontrol kualitas yang disyaratkan dalam standar tersebut.

Pada penelitian berikutnya perlu mempertimbangkan aspek validasi dari perangkat kontrol kualitas yang disusun untuk mengetahui praktik dari penggunaan perangkat kontrol kualitas tersebut untuk memastikan perangkat lunak yang dihasilkan berkualitas.

\section{DAFTAR RUJUKAN}

Clapp, Judith A.; Stanten, Saul F.;. 2011. A Guide to Total Software Quality Control. [book auth.] Judith A. Clapp, et al. Software Quality Control, Error Analysis, and Testing. United States: William Andrew Pub, 2011, pp. 1-99.

Galin, Daniel. 2003. Software Quality Assurance: From Theory to Implementation. Dorchester : AddisonWesley, 2003. 978-0201709452.

Horch, John W. 2003. The Elements of a Complete Software Quality System. Practical Guide to Software Quality Management. Noorwood: Artech House, Inc., 2003.

ISO/IEC. 2007. Software engineering - Software product Quality Requirements and Evaluations (SQuaRE) - Quality Requirements. Switzerland : s.n., 2007.

Nurkasanah, Ika. 2013. Penjaminan Kualitas Pengembangan Perangkat Lunak pada Aplikasi School Social Network (SSN) Berdasarkan Standar IEEE 730-2002. Surabaya: ITS, 2013. Undergraduate Thesis.

Quality Market: Design and Field Study of Prediction Market for Software Quality Control,. Krishnamurthy, J. and Nyshadham, E. 2011. 2011. System Sciences (HICSS), 2011 44th Hawaii International Conference on. pp. 1-9.

Tian, Jeff. 2005. Software Quality Engineering: Testing, Quality Assurance, and Quantifiable Improvement. Hoboken: Wiley-IEEE Computer Society Press, 2005. 978-0-471-71345-6.

Wagner, Stefan. 2013. Software Product Quality Control. s.l.: Springer-Verlag Berlin Heidelberg, 2013. 